\author{
Jerzy Łopat OFMConv ${ }^{1}$ \\ 0000-0002-4219-5403
}

Wyższe Seminarium Duchowne OFM Conv., Łódź-Łagiewniki

\title{
Od mistycznej intuicji św. Franciszka do kontuicji św. Bonawentury
}

Celem niniejszego artykułu jest ukazanie, w jaki sposób św. Bonawentura z Bagnoregio, siódmy generał Zakonu Braci Mniejszych po św. Franciszku, próbował wyjaśnić intuicję mistyczną Biedaczyny z Asyżu. Zostanie podjęta refleksja nad tym, jak można objaśnić intelektualnie intuicję mistyczną, która ze swojej najgłębszej natury jest pozaintelektualna, bowiem wynika z samego serca doświadczenia mistycznego, przekraczającego wszelkie zdolności percepcyjne ludzkiego intelektu. Należy przy tym pamiętać, że średniowieczna scholastyka opracowała

1 Jerzy Łopat OFMConv - ur. w 1964 roku w Jeleniej Górze; od 1983 roku związany z Zakonem Braci Mniejszych Konwentualnych. W 1990 roku obronił na KUL-u pracę magisterską z teologii średniowiecznej, w 1995 roku ukończył studia magisterskie z dziedziny filozofii współczesnej na Wydziale Filozofii Teoretycznej (KUL), a w roku 2001 obronił pracę doktorską z dziedziny filozofii średniowiecznej. Wydał m.in.: Współczesne interpretacje poznania Boga według św. Bonawentury (Niepokalanów 1999), Rozumienie Natury Boskiej u św. Bonawentury (Niepokalanów 2017), Leksykon postaci franciszkańskich z XIII i XIV wieku (Niepokalanów 2011). Opublikował 60 artykułów z dziedziny myśli średniowiecznej, franciszkanizmu, filozofii i teologii, duchowości zakonnej oraz współczesnych problemów cywilizacyjnych. Wykładał w Instytucie Teologicznym w Kaliszu, na Uniwersytecie Stefana Kardynała Wyszyńskiego w Warszawie i w Wyższym Seminarium Duchownym w Łodzi-Łagiewnikach. E-mail: o.jerzy. lopat@wp.pl. 
specyficzny techniczny język, który mocno utrudnia percepcję myśli. Co więcej, zamiar Bonawentury wydawał się „karkołomny” z samej materii problemu, który podjął. Układ artykułu jest następujący: 1. Intuicja mistyczna św. Franciszka; 2. Kontynuacja św. Bonawentury; 3. Ocena kontuicji w świetle wybranych analiz badaczy myśli Bonawentury; 4. Ocena kontuicji w świetle współczesnej filozofii poznania w nauczaniu wybranych autorów.

\section{Intuicja mistyczna św. Franciszka}

Święty Franciszek z Asyżu jest przykładem mistyka, jednego z największych w dziejach Kościoła, u którego łatwo jest zauważyć intuicję mistyczną, stanowiącą wewnętrzną osnowę doświadczenia mistycznego. Bowiem to mistyczna intuicja Bożej Obecności pozwala mistykowi: odczuwać, przeżywać i mistycznie percypować samego Boga. To dzięki tej mistycznej intuicji św. Franciszek odbierał bliskość Pana w swoim życiu, dlatego Jezus Chrystus to był jego Boski Przyjaciel, wręcz Boski Oblubieniec. Wszystko, co rozgrywało się wokół niego, to było zrządzenie dobrego Boga, ponieważ nawet Franciszkowe cierpienie wynikało z bliskości Jezusa Cierpiącego. Cały świat stworzony był dla św. Franciszka jakby wielką księgą, w której on widział - w rzeczach i poprzez rzeczy samego Boga. Tak można syntetycznie zarysować mistyczną intuicję św. Franciszka.

\section{Kontuicja św. Bonawentury}

Kiedy 2 lutego 1257 roku Bonawentura został wybrany na ministra generalnego Braci Mniejszych, to w bardzo krótkim czasie udał się do Umbrii, ziemi świętego Franciszka, by spotkać się z braćmi, którzy jeszcze pamiętali Biedaczynę, aby od nich, jak ze źródła zaczerpnąć wiedzę o świętym Założycielu. Później wielokrotnie, jak na przykład w 1260 roku, był znowu obecny we Włoszech, spotykał się i długo kontaktował się z bratem Leonem, Rufinem, Masseo i wieloma innymi socii św. Franciszka. Dlatego 
bonawenturiańskie piśmiennictwo duchowe i teologiczne było osadzone na solidnej wiedzy o życiu i duchowości Biedaczyny z Asyżu. Jednak przed młodym profesorem i ministrem generalnym Bonawenturą stanęło bardzo trudne zadanie, jak w precyzyjnych terminach intelektualnej scholastyki wyrazić ulotną i prawie niemożliwą do racjonalnego uchwycenia istotę mistycznego doświadczenia Boga przeżytego przez Asyżanina, które zawierało się przecież w mistycznej intuicji obecności Boga.

Bonawentura, jako wykładowca Uniwersytetu Paryskiego, zastosował do wyjaśnienia mistycznej intuicji św. Franciszka następujące teorie: teorię egzemplaryzmu (pochodzącą od Platona), teorię zmysłów duchowych (zaproponowaną przez Orygenesa) oraz swoją własną teorię tzw. kontuicji.

Dzięki bonawenturiańskiej wersji egzemplaryzmu ${ }^{2}$, bardzo oryginalnej, Doktor Seraficki mógł wyrazić. jak św. Franciszek postrzegał cały świat jako dzieło dobrego Boga i dlaczego cały stworzony świat „mówił o Bogu do św. Franciszka"3. Egzemplaryzm stanowi wręcz istotę metafizyki i teologii Bonawentury. Tylko Bóg jest bytem samoistnym, natomiast wszystko inne jest bytem o tyle, o ile partycypuje w Bycie Boskim jako jego: ślad (cień), obraz, podobieństwo. Wszystko co istnieje jest jedynie śladem (exemplum) swego Boskiego Wzorca, którym jest sam Bóg. Rzeczy zostały stworzone w czasie według idei wzorczych tkwiących odwiecznie w umyśle Boga. Zatem Boga należy szukać jako ostatecznego Wzoru, wychodząc od stworzeń, które są znakami prowadzącymi do Niegón, szczególnie od samego człowieka5.

2 Więcej na ten temat zob.: J. Łopat, Rozumienie Natury Boskiej u św. Bonawentury, Niepokalanów 2017, s. 25-63.

3 Warto w tym miejscu nadmienić, że to jest właściwy punkt mówienia o ekologicznym nastawieniu św. Franciszka, a nie jakieś abstrakcyjne pojęcia „umiłowania przyrody” dla niej samej, jak nam się dzisiaj to powszechnie wmawia.

4 Egzemplaryzm (łac. exemplaris - wzór, przykład, model) - nurt w filozofii podkreślający, że świat został stworzony według idealnych wzorców rzeczy istniejących w umyśle B o ga. Naukę tę już w okresie starożytnym spotykamy u Platona, potem u Fil on a Aleksandryj ski ego, następnie u św. August yna, a jednym z ważniejszych jego przedstawicieli w okresie średniowiecza jest właśnie B on awentura z Bagnoregio.

${ }^{5}$ „Według Bonawentury byt skończony odzwierciedla Trójcę na trzy sposoby: ślad (lub cień), obraz i podobieństwo. Jako ślad - Trójca daje się dostrzec w całym jestestwie dzięki istnieniu trzech transcendentalnych właściwości: jedności, prawdy, dobra, które 
Bonawenturiańska wersja teorii zmysłów duchowych ${ }^{6}$ deklaruje: kiedy człowiek odrywa się od świata zewnętrznego, to muszą być włączone wewnętrzne zmysły do wewnętrznego poznawania Oblubieńca duszy, czyli Boga $^{7}$. Bóg bowiem na tym etapie naszego poznawczego dążenia do Niego staje się właściwie całym naszym poznawanym i przeżywanym światem. Bonawentura następująco charakteryzuje te zmysły (określane jako wewnętrzne lub duchowe) ${ }^{8}$ : stanowią one „doskonały zmysł Boga. I ten zmysł sprawia, że kontemplujemy i posiadamy stan spokoju oraz radosny poryw. Gdyż w pokoju może istnieć pełnia rozmyślania i kontemplowania"9. Ten opis można doprecyzować stwierdzeniem, iż ten zmysł Boga [to jest

są odblaskiem trzech doskonałości przypisywanych tradycyjnie Bogu: mocy, mądrości i dobroci. Jako obraz - Trójca ukazuje się w bytach intelektualnych, obdarzonych pamięcią, rozumem i wolą; te trzy władze duszy są jakby echem życia samej Trójcy świętej. Wreszcie jako podobieństwo - Trójca daje się jeszcze głębiej poznać poprzez byty uświęcone łaską i trzema cnotami teologalnymi; dzięki wierze, nadziei i miłości, które je ożywiają, byty te wchodzą w relacje z Osobami boskimi, które w niej mieszkają. Tak oto świat widzialny, dusza i Bóg są ze sobą zespoleni subtelnym pasmem relacji triadycznych, które odzwierciedlają stwórcze i odkupieńcze działanie Boga trynitarnego" (B. de Margerie, Osoba ludzka śladem, obrazem i podobieństwem Boga Trójcy, w: Tajemnica Trójcy Świętej, red. L. Balter, Poznań 2000, s. 391 [Kolekcja Communio, 13]).

6 Na temat ogólnego wprowadzenia do zagadnienia zmysłów duchowych zob. np.: W. Zyzak, Zmysły duchowe w duchowości chrześcijańskiej, „Analecta Cracoviensia” 48 (2016), s. 255-276. Natomiast więcej na temat samej bonawenturiańskiej wersji teorii zmysłów duchowych zob. J. Łopat, Rozumienie Natury Boskiej..., dz. cyt., s.70-73.

7 Dopóki człowiek jest zasadniczo zajęty poznawaniem świata, to trudno będzie mu odkrywać obecność Boga (tylko poprzez ślady, cienie i obrazy, itp., czyli poprzednie etapy), kiedy odwraca się od świata i zwraca się do Boga, to się otwiera na Bożą Obecność. Można wtedy powiedzieć, że „Bóg uobecnia siebie w taki sposób, że może być duchowo wyczuwalny; dopiero kiedy człowiek zwraca uwagę na tę obecność, rozumie, czym są zmysły duchowe" (G. F. LaNave, Bonawentura, w: Duchowe zmysty. Percepcja Boga w zachodnim chrześcijaństwie, red. P. L. Gavrilyuk, S. Coakley, tłum. A. Gomola, Kraków 2014, s. 207).

8 Należy tutaj sprecyzować, że Bonawentura znał kategorię Arystotelesowską wewnętrznych władz człowieka będących w relacji z naszymi zmysłami zewnętrznymi. Chodzi tutaj o wyobraźnię, pamięć i władzę wydawania sądów; kiedy Bonawentura wspomina o zmysłach wewnętrznych, to ma na myśli władze naszej duszy, o ile odnoszą się one do spraw Boskich.

9 Por. Św. Bonawentura, Konferencje o sześciu dniach stworzenia albo oświecenia Kościoła [Collationes in Hexaëmeron] Wydanie synoptyczne tekstu oryginalnego redakcji A oraz B z przekładem polskim, tłum. A. Horowski, Kraków 2008 (dalej: Hexa) coll. 23, 27*a, s. 631. 
ten który] „przenosi człowieka w stan doskonałej kontemplacji”" ${ }^{10}$. Tak się dzieje, kiedy zostają spełnione trzy warunki: „a mianowicie spokojny stan wzniosłego zamieszkania, wyraźne spojrzenie przenikliwego rozeznania i ekstatyczny poryw słodkiego pocieszenia" ${ }^{11}$. Doktor Seraficki określa zatem omawiane zmysły wewnętrzne jako: percepcje mentalne kontemplowanej prawdy ${ }^{12}$, albo jako wykorzystanie duchowych spekulacji ${ }^{13}$, albo też określa je jako „wykorzystanie łaski wewnętrznej w odniesieniu do samego Boga proporcjonalnie do pięciu zmysłów"14.

Warto zauważyć, że w tej teorii najsłabszym elementem jest to, iż nie wskazuje ona wystarczająco mocno (przekonująco), co zasadniczo „wiąże" poznawczo człowieka z Bogiem, a tym jest właśnie - kontuicja. Dlatego najpierw należy przyjrzeć się i określić, czym jest owa bonawenturiańska kontuicja ${ }^{15}$. Kontuicja polega na bezpośrednim oraz zbliżonym do intuicyjnego swoistym odniesieniu się do Boskiego Dobra, przyczynującego każdy istniejący i poznawany byt stworzony, przez co ta droga do określenia Boskiego Dobra stanowi właściwie swoisty intuicyjny skrót. Dlatego ta intuicja metafizyczna zostaje ujęta i rozbudowana w koncepcji kontuicji, pojętej jako swoisty (i nieco zbliżony do Platońskiego) wspótogląd dobra odkrywanego we wszystkich stworzeniach, a odnoszacy się do Niestworzonego Boskiego Dobra. Zagadnienie kontuicji miało doniosłe znaczenie w całej myśli Doktora Serafickiego, bowiem pozwalało wyjaśnić naturę ogladowego poznania Boga ${ }^{16}$. Teksty o kontuicji wskazują bowiem, że jest to właśnie pewne poznanie świata stworzonego, poprzez które człowiek

10 Por. Hexa coll. 23, 27*a, s. 631.

11 Por. Hexa coll. 23, 27*b, s. 631. Bonawentura stara się określić duchowe predyspozycje, które muszą zaistnieć w duszy do właściwego zadziałania zmysłów wewnętrznych.

12 Por. np. Doctoris Seraphici S. Bonaventurae, Opera omnia. Commentaria in tertium librum Sententiarum, Quaracchi 1885, s. 737b-738a (dalej: III Sent., d. 34, d. 1, p. I, a. 1, concl.). Tutaj Bonawentura szerzej omawia ten problem.

13 Por. Doctoris Seraphici S. Bonaventurae, Breviloquium, in: Opera omnia. Opuscula varia theologica, tomus 5, Quaracchi 1891 (dalej: Brev., p. V, cap. 6), s. 258 a.

14 Por. np. III Sent., d. 13, dub. 1; t. 3, 291a-292a. Bonawentura omawia tutaj zagadnienie zmysłów wewnętrznych i podaje nawet autorów tejże doktryny, do których się odwołuje: Orygenesa i Augustyna.

15 Więcej na ten temat zob. J. Łopat, Rozumienie Natury Boskiej..., dz. cyt., s. 87-92, 99-103.

16 Termin contuitio można zasadniczo tłumaczyć w duchu platońskim jako współogląd, jakkolwiek nie wyczerpuje to całego bogactwa bonawenturiańskiego pojmowania kontuicji. 
wznosi się do kontuicji tego, co Boskie $e^{17}$. Tak więc zagadnienie kontuicji ani nie było odseparowane od kwestii poznania ${ }^{18}$, ani też nie wprowadzało sprzeczności pomiędzy kontuicją a innymi formami wędrówki do Boga. Intelekt bowiem, gdy tylko rozważa conditiones entis według najbardziej podstawowej relacji przyczyna-skutek, to ",przechodzi od skutku do przyczyny i wznosi się do racji wiecznych"; a ponieważ przyczyna różni się od skutku, stąd też „Pierwsza Przyczyna jest Bytem Pierwszym, natomiast skutek jest bytem stworzonym, Pierwsza Przyczyna jest bytem prostym, skutek jest bytem złożonym"19.

Dlatego wyróżnia się potrójną drogę do odkrycia kontuicji, czyli: drogę rozumowani ${ }^{20}$, drogę doświadczenia ${ }^{21}$ oraz drogę intelektualnego ujmowa$n$ na $^{22}$, które razem zestawione i wzajemnie porównane, pokazują nam, jak intelekt zostaje podniesiony do poziomu boskiej kontuicji (współoglądu) ${ }^{23}$. To podniesienie kontuicyjne jest w ogóle możliwe dlatego, że dusza jest nastawiona na Nieskończone Dobro i Prawdę. Jednak w tym podniesieniu naszej duszy występuje wręcz swoista gradacja od stopni niedoskonałych aż po najbardziej doskonałe przynależne tylko Bogu, stąd też absolutnie pełną i prawdziwą kontuicję, to człowiek będzie posiadał dopiero w niebie ${ }^{24}$.

17 Por. „Kiedy więc spostrzega te rzeczy, wznosi się ku oglądowi Boga, stwierdza, że posiada poznanie nabyte, które obiecywali filozofowie, a pociąga ją ku niemu prawda" (Hexa, coll. 5, 33b, s. 217).

18 Por. Doctoris Seraphici S. Bonaventurae, Opera omnia. Commentaria in Librum Secundum Sententiarum, Quaracchi 1882 (dalej: II Sent., d. 39, a. 1, q. 2, concl., vol. 2, 904a-b).

19 Por. „Sam intelekt, rozważając właściwości bytu pod względem relacji między przyczyną a skutkiem, przechodzi od skutku do przyczyn i dochodzi do odwiecznych idei. Przyczyna różni się od skutku, ponieważ pierwsza przyczyna jest pierwszym bytem, a skutek jest bytem wytworzonym; pierwsza przyczyna jest bytem prostym, a skutek jest złożonym; pierwsza przyczyna jest bytem czystym, a skutek jest bytem mieszanym; pierwsza przyczyna jest bytem niezmiennym, a skutek zmiennym; pierwsza przyczyna jest bytem absolutnym, a skutek zależnym; pierwsza przyczyna jest bytem doskonałym, a skutek bytem cząstkowym. A zatem te prawdy są najzupełniej pewne"(HEXA, coll. 5, 28; s. 213).

20 Por. Hexa, coll. 5, 29; s. 213-215.

21 Por. Hexa, coll. 5, 30; s. 215.

22 Por. Hexa, coll. 5, 31; s. 215.

23 Por. Hexa, coll. 5, 32; s. 215-217.

24 Por. „Intelekt i wola duszy rozumnej zmierzają do nieskończonego dobra i prawdy ujmowanej jako nieskończona. Ten ruch może się jednak dokonywać na sześć sposobów: jako wiara, rozumowanie, cześć, oglądanie, przekraczanie i pojmowanie. Pierwszy z tych 
Ponieważ ludzki intelekt jest skończony, ale też jest w pewnej możności w stosunku do nieskończoności (czyli jest otwarty na nieskończoność = Capax Dei), więc „nic, co jest tylko skończone nie może zaspokoić jego pragnień, a to zatem oznacza, że nasze naturalne poznanie jest nieograniczone" i stąd „dusza nie zadawala się poznawaniem jakiegoś przedmiotu poznawania, ale ostatecznie dąży do poznania takiego Przedmiotu, który zawiera w sobie wszystko, co jest poznawane i w którym wszystko jest poznawane" ${ }^{25}$. Należy jednak wskazać, że sama możliwość uzyskania tego podniesienia kontuicyjnego nie wynika z natury naszego ludzkiego intelek$\mathrm{tu}^{26}$, gdyż ,jest niemożliwe, aby jakieś stworzenie (choćby najbardziej godne), przy pomocy naturalnego światła swojego intelektu, mogło dosięgnąć i oglądać Boskie światło i to samo w sobie" ${ }^{27}$. Dlatego kontuicja, która spetnia to najbardziej wzniosłe zadanie stojące przed ludzkim intelektem, jest wizja czy też rodzajem metafizycznej intuicji, która ma swoje wymagania $^{28}$.

sposobów jest niedoskonały i charakterystyczny dla pielgrzymki doczesnej; ostatni jest najdoskonalszy oraz właściwy wiecznej i nieskończonej Trójcy; drugi i trzeci dotyczą postępu w trakcie pielgrzymki; czwarty i piaty - spełnienia w ojczyźnie niebieskiej. W doczesności możemy bowiem Boży bezmiar kontemplować, rozumując i czcząc, w niebie możemy oglądać, kiedy staniemy się podobni Bogu, i przekraczać, kiedy będziemy już całkowicie upojeni" (św. Bonawentura, O wiedzy Chrystusa [Quaestiones disputatae De Scientia Christi], tłum. M. Olszewski, w: Święty Bonawentura, O wiedzy Chrystusa. O tajemnicy Trójcy, Kęty 2006, s. 120 (dalej: DSC, q. 6, concl.).

25 Por. „Cognitio enim animae naturalis est cognitio non arctata; unde nata est quodam modo omnia cognoscere, unde non impletur cognitio eius aliquo cognoscilibili, nisi quod habet in se omnia cognoscibilia et quo cognitio omnia cognoscuntur". Doctoris Seraphici S. Bonaventurae, Opera omnia, Commentaria in primum librum Sententiarum, Quaracchi 1882, vol. 1, 40b (dalej: I Sent., d. 1, a. 3, q. 2, concl.).

26 Por. „Quantumcumque mens in contemplatione profecerit, non pervenit ad contuitum Dei”. Et communiter doctores in hoc concordant [...]. quod quamdiu sumus in hoc corpore, peregrinamur a Domino et per fidem ambulamus, non per speciem" (II Sent., d. 23, a. 2, q. 3, concl.; vol. 2, 544b).

27 Por. „Ergo impossibile est, quod aliquis ad contuitum supernae lucis perveniat per illuminationem aliquam naturalem, vel acquisitam, nisi Deus suae luminositatis radium immittat [...] ergo impossibile est, quod aliqua creatura, quantumcumque nobilis, divinam lucem in se ipsa per naturam cognoscat” (II Sent., d. 3, a. 2, q. 2, 6; vol. 2, 123a).

28 Por. „Ad simplicem autem contuitum sufficit, quod sit convenientia ordinis, sed ad cognitionem comprehensionis requiritur convenientia secundum quandam aequalitatem sive adaequationem. Et ideo non sequitur, quodsi anima creata non possit comprehendere 
Kontuicja posiada swoją pewnego rodzaju bezpośredniość, która jest przeciwstawiana dyskursywności (właściwej dla ludzkiego skończonego intelektu), ale to nie znaczy, że poprzez kontuicję można bezpośrednio uchwycić poznawczo samego Boga. Kontuicja jest tylko swoistym poznaniem pośrednim, gwarantującym intelektualne uchwycenie obecności Nieskończonego Boga w i poprzez natury stworzone [skończone], stanowi zatem samo sedno bonawenturiańskiego egzemplaryzmu. To docieranie do Boga na drodze kontuicji jest już konstytuowane poprzez nasze odkrywanie Pierwszej Przyczyny przez jej ślad pozostawiony w każdym stworzeniu. Charakteryzując samą kontuicję, należy też wskazać na jej wyższą doskonałość od innych typów poznawania (np. dyskursywnego), bowiem najdoskonalszy typ poznania, czyli oglad kontuicyjny, jaki kiedykolwiek przysługiwał człowiekowi ${ }^{29}$, to właśnie ten w stanie niewinności (przed grzechem pierworodnym): gdzie był to ogląd bezpośredni, jakkolwiek dokonywał się on poprzez obraz (czyli zwierciadło), to jednak obywał się bez tajemnicy i bez ciemności ${ }^{30}$. Według nauki Bonawentury można bowiem, poznawać świat stworzony i poszukiwać prawdy tych bytów dla nich, tylko w nich samych; ale poznajemy rzeczy stworzone także jako skutki Boskiego stworzenia, a przez to stworzenia pozwalaja nam lepiej poznać Boga ${ }^{31}$. Dlatego tak wyraźnie na płaszczyźnie metafizycznej odkrywa się, że każdy skutek jest pośrednikiem do poznania swojej przyczyny, stąd też poprzez analizę różnych stworzeń poznaje się ich Przyczynę - Boga ${ }^{32}$. Stąd też musi istnieć jakiś specjalny typ poznawczego uchwycenia owej

infinitatem, quod non possit intueri luminis fontem" (III Sent., d. 14, a. 1, q. 3, concl.; t. 3, 305a).

${ }_{29}$ Wyraźnie tutaj odkrywamy platońskie i neoplatońskie korzenie tejże doktryny bonawenturiańskiej, co jest także dziedzictwem augustyńskim w myśli Doktora Serafickiego.

30 Por. „Cum imago non erat vitiata, sed deiformis effecta per gratiam, suficiebat liber naturae in quo se exerceret homo ad contuendum lumen divinae sapientiae" (Brev., p. 2, cap. 12; vol. 5, 230b).

${ }_{31}$ Por. „Praesentius est aliquid dupliciter in ratione cognoscibilis: vel secundum effectum, vel secundum se. Secundum se notior est frater, secundum effectum notior est Deus" (I Sent., d. 17, p. 1, dub. 2; t. 1, 304b).

32 Por. "Cognoscebat Deum per medium, aut sine medio; dicendum, quod per medium, scilicet per effectum"(II Sent., d. 3, p. 2, a.2, q. 2, concl. ad 6; t. 2, 124a). 
Boskiej Obecności w stworzeniu ${ }^{33} \mathrm{i}$ to właśnie chwyta kontuicja. Jednocześnie do uzyskania pewności ludzkiego poznania nie wystarcza tylko sam wpływ wiecznego światła, ale także konieczna i wręcz potrzebna jest równieżjego Obecnośs ${ }^{34}$ - uchwytywana właśnie poprzez tę kontuicję, bowiem owa pewność poznawcza gwarantowana jest przez absolutną i niezmienną Prawdę Boską na nas oddziaływującą.

To zespolenie obu porządków (metafizycznego i poznawczego) wynika również z samego określenia wzajemnych relacji pomiędzy nimi, ponieważ przyczyna bytowania wyprzedza przyczyna poznania, tak więc, jak byt stworzony jest w zależności od Pierwszej Przyczyny, analogicznie stworzone poznanie jest zależne jest od poznania na ,poziomie” Niestworzonym; nie znaczy to, że rzeczy stworzone nie posiadają własnego bytu i własnego działania poznawczego ${ }^{35}$, ale tylko to, że sama Boska Mądrość nieustannie wspótpracuje z ludzkim świattem stworzonym i zachowuje je w istnieniu ${ }^{36}$. Dlatego wszelkie stworzone racje poznawania zawierają $\mathrm{w}$ sobie racje niestworzone, bowiem żadna władza stworzona nie może sobie pozwolić na działanie bez Boga ${ }^{37}$. Jednak nie można uznać, aby owe racje wieczne, były jedyną

33 Por. „Omne enim quod cognoscitur, cognoscitur per aliquid praesens; si igitur Deus cognoscitur, necesse est, quod per aliquid praesens intellectui cognoscatur; praesens autem voco hic, secundum quod Augustinus vocat, quod praesens est intellectui ad vivendum. Aut igitur cognosco Deum per hoc quod est praesens mihi [...]. Si autem cognosco Deum per hoc quod est mihi, hoc potest esse tripliciter: aut per hoc quod est praesens mihi in effectu proprio; et tunc est contemplatio, quae tanto est eminentior, quanto effectum divinae gratiae magis sentit in se homo, vel quanto etiam melius scit considerare Deum in exterioribus creaturis" (II Sent., d. 23, a. 2, q. 3, concl.; t. 2, 545a).

34 Por. „Do poznania pewnego nie wystarczy wpływ światła wiecznego bez jego obecności z tego względu, że nic stworzonego nie może utrwalić duszy w doskonałej pewności, jeżeli nie osiągnęła ona niezmiennej prawdy i nieomylnego światła”(DSC, q. 5, concl.; s.109).

35 Por. „Na 3, że dusza ma sama przez się wiedzę o rzeczach niecielesnych, odpowiadam, że jak w działaniach stworzeń nie jest wykluczone współdziałanie Stwórcy, tak stworzona zasada poznania nie wyklucza niestworzonej, lecz raczej ją włącza” (DSC, q. 4; concl. ad 3; s. 99).

36 Por. „Et Deus dicitur docere, non inspirando sive infludendo, sed cooperando lumini dato et conservando illud." (II Sent., d.7, p.2, a.1, q.1, concl. ad 6; t. 2, 191b).

37 Por. „Nullus potest aliquid addiscere, nisi Deus doceat. Hoc enim non dicitur, quia omnis cognitio sit infusa, sed quia lumen creatum non potest perficere operationem suam absque cooperatione luminis increati, per quod illuminatur omnis homo, qui venit in hunc mundum [...] haec enim dicta sunt, non quia Deus sit tota causa, sed quia sine ipso non potest agere aliqua virtus creata" (II Sent., d. 28, a. 2, q. 3, concl.; t. 2, 690a). 
i całkowitą oraz właściwą rację ludzkiego poznania" ${ }^{38}$, gdyż to by sugerowało, że istnieje jakaś możliwość ludzkiego wniknięcia w samo Boskie Światło, a to jest przecież niemożliwe ${ }^{39}$. Jednocześnie należy zauważyć, że „niewielu jest tych, którzy wiedzą, że w ich działaniu intelektualnym mają udział owe wieczne racje, co więcej, bardzo nieliczni chcą w to uwierzyć, gdyż wydaje się im rzeczą bardzo trudną do uznania, że nasz intelekt, jeszcze nie podniesiony do stanu kontemplacji rzeczywistości wiecznej, mógł w ten sposób [na drodze kontuicji] dotrzeć do intelektu Boskiego i Jego Idei" ${ }^{40}$. Stąd kontuicja nie ma możliwości wniknięcia w same Boskie Idee, a tylko jest swoistą kon-tuicją, czyli ich wspót-ujęciem (o charakterze intuicyjnego przybliżenia się do nich), gdyż umysł przez kontuicję nie poznaje Boskich Idei w Bogu, ale ujmuje je w sobie samym poprzez aktualizację poznawczą realizującą się w spontanicznym poruszeniu umysłu w kierunku Idei Boskich ${ }^{41}$.

Zaprezentowana bonawenturiańska kontuicja jest więc specyficznym poznawczym dojściem do Boga, w jego stworzeniach i poprzez jego stworzenia. Ta poznawcza droga wymaga prawdziwie metafizycznego podejścia

38 Por. „Nie widzimy całkowicie wyraźnie tych zasad w sobie, toteż nie są one całą zasadą poznania, lecz razem z nimi potrzebne jest światło stworzone zasad dowodzenia i podobizny rzeczy poznanych; to wszystko składa się na właściwą zasadę poznania każdego przedmiotu poznania" (DSC, q. 4; concl. ad 15; s.101).

39 Por. „W trakcie pielgrzymki doczesnej nie sam rozum wieczny powoduje poznanie, ale czyni to wraz z prawdą zasadę i nie szczególnie z siebie, ale powszechnie. Dlatego tez nie wynika z trudności, że wieczny rozum jest nam znany jako taki, ale tylko, że jest znany, o ile rozbłyskuje w swoich zasadach i w swojej ogólności. Tak więc w jakiś sposób rozum wieczny jest dla nas najpewniejszy, ponieważ nasz intelekt nie może w żaden sposób pomyśleć, że go nie ma, czego nie można powiedzieć o żadnej prawdzie stworzonej” (DSC, q. 4, concl. ad 16; s. 101).

40 Por. „Tego rodzaju zasady prowadzą intelekty uczonych, ale dla intelektów mędrców są miejscem spoczynku oraz powrotu. A ponieważ nieliczni są ci, którzy docierają do nich w taki sposób, nieliczni są mędrcy, choć jest wielu uczonych. Niewielu jest takich, którzy wiedzą, że osiągnęli te zasady, a jeszcze mniej jest takich, którzy w to wierzą, ponieważ intelektowi, który jeszcze nie wzniósł się do kontemplowania rzeczy wiecznych, czymś trudnym zdaje się mieć Boga obecnego w takiej bliskości, choć przecież Paweł powiada, jak czytamy w 17 rozdziale Dziejów Apostolskich, że «niedaleko jest od każdego z nas»" (DSC, q. 4, concl. ad 19; s. 102).

${ }^{41}$ Por. „Intellecus vero, sive circa creaturam sive circa Creatorem negotietur, semper referetur ad rationes aeternas, ad quas per creaturas etiam elevat contemplandas" (III Sent., d. 35, a.un[icus], q. 3, concl. ad 2; t. 3, 779a). 
do poznawanej rzeczywistości. Kontuicja polega więc na niezatrzymywaniu uwagi tylko na samych stworzeniach, ale koniecznie postuluje uwzględnienie ich najbardziej metafizycznego odniesienia do ich Pierwszej Przyczyny, czyli Boga ${ }^{42}$. Kontuicja stanowiła więc nie tylko próbę odczytania tego najbardziej podstawowego odniesienia na naszej poznawczej drodze do Boga, ale także stanowiła ważny łacznik katafatyczny, który spinał teorię poznania z metafizyką i właśnie dlatego kontuicja pozostaje wręcz niezrozumiała poza jej kontekstem metafizycznym. Dlatego zostały wyróżnione dwie płaszczyzny tego odkrywczego działania kontuicji: płaszczyzna egzystencjalna - kontuicja ujmuje samą Obecność Boską w stworzeniach, przez co ta Obecność jest współuchwytywana (stąd kontuicja) w tych stworzeniach; płaszczyzna treściowa - kontuicja uchwytuje to, co najważniejsze treściowo w bycie, oraz co go odnosi w jego najważniejszych relacjach do samego Stwórcy ${ }^{43}$. Dlatego kontuicja w swych metafizycznych fundamentach polega zasadniczo na odczytaniu dobra jako fundamentu każdego stworzenia oraz intuicyjnym odniesieniu go do Boskiego Dobra. Stąd kontuicja jest stale obecna u Bonawentury: przy analizach zagadnienia natury i ostatecznego charakteru poznania, przy omawianiu źródła pewności ludzkiego poznania i wiedzy; przy prezentacjach zagadnień metafizycznych, takich jak: partycypacji, hierarchizacji, wzorczości czy też zagadnienia przyczynowości; ale też stanowi sedno całej jego teorii poznania Boga, Jego Boskiej Natury i fundamentów tejże Natury, czyli Boskiego Dobra, pojętego jako Źródło i Przyczyna stworzonej rzeczywistości.

42 Por. „Na 14, że zasady bycia i poznania są identyczne, odpowiadam, że jak wewnętrzne zasady bycia bez owego pierwszego źródła zewnętrznego, którym jest Bóg, nie starczą by być, tak zasady wewnętrzne nie starczą do pełnego poznania. Toteż mimo że owe zasady są w jakiś sposób zasadą poznania, to nie wykluczają przez to z naszego poznania owej pierwszej zasady poznania, tak samo jak nie wykluczają w rzeczywistym byciu zasady pochodzącej od aktu stworzenia" (DSC, q. 4, concl. ad 14; s. 101).

43 Komentarz do tej kwestii zob. np.: L. Veuthey, Filozofia chrześcijańska św. Bonawentury, tłum. E. I. Zieliński, Niepokalanów 1996, s. 50. 


\section{Ocena kontuicji na podstawie wybranych analiz badaczy myśli Bonawentury ${ }^{44}$}

Jean de Dieu de Champsecret uznał, iż kontuicję należy określićjako bardzo swoistą teorię intuicji, ale bez uwyraźnionego jej ostatecznego przedmiotu dla tej specyficznej, bo całościowej intuicji ${ }^{45}$. Ponieważ jego analizy zagadnienia kontuicji mają charakter psychologiczny i częściowo fenomenologiczny, dlatego bardzo precyzyjnie został wyakcentowany problem znaczenia kontuicji dla samego poznającego umysł. Jednak Jean de Dieu de Champsecret ani nie określił natury kontuicji, ani też jej nie zdefiniował. Dlatego ta propozycja interpretacji bonawenturiańskiej kontuicji, sygnalizuje nam tylko, że owa kontuicja jest tylko swoistą formą intuicji sięgającej bezpośrednio do źródła prawdy ${ }^{46}$. Kontuicja pozwala więc odczytać intuicyjnie sam fakt obecności Bytu Boskiego, stąd też według tego autora mamy do czynienia z kon-tuicją. Taka próba wyjaśnienia natury kontuicji podkreśla znaczenie podmiotowego (subiektywnego) uwarunkowania tej swoistej intuicji, ale nie daje wystarczającego materiału do obiektywnego (oraz zewnętrznego do poznającego podmiotu) określenia natury kontuicji.

Zbliżone stanowisko zajmował Henry Duméry, który uważał, że bonawenturiańskie terminy contuendum, contueri czy też contuitus, wcale nie oznaczają intuicji chwytajacej Boga, ale raczej sugerują tylko pewne bezpośrednie uchwycenie, ich skutków (tej kontuicji), w których to skutkach (tj. stworzeniach) znajduje się Boga Stwórcy konieczna Obecność. Tak rozumiana kontuicja, to jakby „swoisty duchowy wzrok namierzający w konkretnych poznawanych stworzeniach ich Ostateczne Odniesienie", dlatego kontuicja byłaby jakimś bardzo specyficznym i wyjątkowym aktem ludzkiego poznawania, aktem najbardziej syntetycznym i aktem o naturze totalnej ${ }^{47}$. Ta próba wyjaśnienia kontuicji ma charakter

44 To zagadnienie omawiam według: J. Łopat, Rozumienie Natury Boskiej..., dz. cyt., s. 93-99.

45 J. de Dieu de Champsecret, Itinéraire de l'Âme en elle-męme, Blois 1956, s. 67-101.

${ }^{46}$ Por. „Elle désigne l'esprit se connaissant et, par là, connaissant déjà les vérités qui fondent, règlent et expliquent tout et lui-même en dernière analyse" (J. de Dieu de Champsecret, Itinéraire de l'Âme en elle-męme, dz. cyt., s. 73).

47 H. Duméry, Itinéraire de l'esprit vers Dieu, Paris 1960, por. zwłaszcza s. 57-65. 
syntetyzujacy: wspomniane uwarunkowania podmiotowe (subiektywne i psychologizujące) oraz wymiar antropologiczny, akcentujący osadzenie tej kontuicji na naturze ludzkiej.

Jeszcze bardziej wyakcentował ów charakter antropologiczny Raniero Sciamannini. Ponieważ we władzach człowieka (intelekcie i woli) zapisane sąjego istotowe dążenia do poznania i kochania Boga, stąd muszą mieć one swój adekwatny przedmiot dążeń. Dlatego właśnie owe swoiste przejście intelektu i woli: od tego, co skończone do tego, co nieskończone; od tego, co przygodne do tego, co absolutne; dokonuje się na mocy aktualizacji ich potencjalności oraz swoistej proporcjonalności względem Bytu Boskiego. Wyjaśnia się to następująco: intelekt poznając, dostrzega jeden ze swoich kresów (czyli ten kresstworzony), ale także spontanicznie, właśnie poprzez kontuicję może odnosić się i poznawać drugi kres tego proporcjonalnego przyporządkowania. Dlatego w swoim poznaniu uzyskuje najbardziej istotną treść, najbardziej stałą i absolutnie pewną wiedzę. Kontuicja jest więc według tego autora jakby analogiczna percepcja obecności Bytu Boskiego odkrywaną we wszystkich bytach stworzonych, analogicznie jak jest obecny model we wszystkich swoich kopiach. Kontuicja chwyta więc intuicyjnie samą Obecność Natury Stwarzającej i nieustannie podtrzymującej to stworzenie w jego istnieniu. Jednocześnie też kontuicja wyraża ciągły wysiłek ludzkiego intelektu do uchwycenia w kontemplacji poznawczej tego, co jest tą wzorczością sama w sobie, a co odkrywa się poprzez „duchowe stopniowe wznoszenie się ku wzorom coraz to bardziej duchowym i transcendentnym", czyli sama kontuicja odnosi się również do Idei Wzorczych ${ }^{48}$.

Zaprezentowane powyżej stanowisko Sciamanniniego wręcz apriorycznie postuluje konieczne istnienie Obiektu (tj. Boga) dla naturalnych dążeń ludzkich władz duchowych oraz równie apriorycznie zakłada pewna i uzasadniona możliwość poznawczego dotarcia do Boga. Na bazie wcześniej zasygnalizowanych tekstów Doktora Serafickiego można raczej zauważyć, że ta kontuicja może w jakiś sposób dotykać istnienia Bytu Nieskończonego, ale tylko dlatego, że Niestworzona Boska Natura i Boskie Idee Wzorcze posiadają działanie aktywizujace względem ludzkiego bytu

48 Por. P. R. Sciamannini, La contuizione bonaventuriana, Firenze 1957, por. zwłaszcza s. $112-113$. 
i intelektu. Wynika to z najbardziej podstawowego metafizycznego faktu, że tylko to, co samo jest w akcie, może pociągać to, co jest w możności (nie odwrotnie). Dlatego to, rozważając zaproponowaną przez Sciamanniniego interpretację wyjaśniającą zagadnienie kontuicji, raczej należy zauważyć, że przedstawiana kontuicja ma za zadanie co najwyżej wyrażać owe ludzkie intuicyjne odczytanie tego aktywizującego działania Bytu Boskiego i Boskiej Mądrości na człowieka i na jego skończony intelekt. Cała ta interpretacja posiada niewątpliwie charakter wybitnie antropologiczny. Znaczącąjest rola samego platonizmu w tym ujęciu kontuicji bonawenturiańskiej.

Jeżeli za Jeanem Marią Bissenem uwzględni się całą historyczną ewolucję zagadnienia poznania intuicyjnego (w który wpisuje się też kontuicja), a także połączy się ten epistemologiczny problem z platońskim egzemplaryzmem, to kontuicję pojmuje się jako bardzo swoistą intuicję, którą posiada każdy poznający intelekt, gdy poznaje cały otaczający go świat bytów stworzonych (skończonych). Jednak ta swoista intuicja nie jest intuicją chwytajaca sam Byt Nieskończony, ale jest tylko intuicyjnym uchwyceniem owej bezpośredniej oczywistości istnienia Boskiego Bytu, która przecież gwarantuje i konstytuuje istnienie całej rzeczywistości stworzonej. Stąd też sama bonawenturiańska nazwa tej specyficznej intuicji wskazuje nam właściwie tylko na kon-tuicje - chwytająca intuicyjnie ów bezpośredni i konieczny stosunek stworzenia do Bytu Nieskończonego ${ }^{49}$. Stąd też kontuicję można ująć jako epistemologiczne wyrażenie metafizycznej teorii egzemplaryzmu ${ }^{50}$.

Swoiste rozwinięcie ukazanego stanowiska ${ }^{51}$ Jeana Bissena zaproponował nam Étienne Gilson ${ }^{52}$. Wykazywał on, że kontuicja stanowi pośrednią

49 J. M. Bissen, L’exemplarisme divin selon saint Bonaventure, Paris 1929; por. zwłaszcza metafizyczne analizy tegoż zagadnienia na s. 223.

50 Co niewątpliwie stanowi próbę wyjaśnienia zagadnienia kontuicji tylko w oparciu o jeden (ale za to uznany za dominujący) element w całej doktrynie Bonawentury.

51 Przedstawiane w tym paragrafie interpretacje wyjaśniające bonawenturiańską koncepcję kontuicji nie są zestawione w porządku chronologicznym, ważnym dla historyka filozofii, ale są zaprezentowane w taki sposób, aby można było odczytać ich coraz to większe filozoficzne zaawansowanie, tak konieczne przy metafizycznym wyjaśnianiu natury kontuicji (wyeksponowany więc zostaje ich walor treściowy).

52 Por. J. Łopat, Współczesne interpretacje poznania Boga według św. Bonawentury, Niepokalanów 1999, s. 53-56, 86-88. 
aprehenzję, czyli ujęcie samej obecności Bytu Boskiego, związane z poznawaniem jakiegoś przedmiotu, gdzie Boska Obecność jest w jakiś sposób implikowana w samej obecności stworzeń (czyli skutków), które przecież wynikaja ze stwórczej działalności Boskiej Przyczyny Stwarzającej ${ }^{53}$. Ponieważ jednak w przypadku myśli Bonawentury nie mamy do czynienia z intuicyjnym ujęciem, czyli bezpośrednim widzeniem samego Boga, a tylko ta kontuicja jest swoistą formą intuicji towarzyszącej, która to sygnalnie odnosi do obecności Pierwszej Przyczyny ${ }^{54}$, stąd też jest to tylko specyficzna - kon-tuicja ${ }^{55}$.

Dosyć zbliżone jest stanowisko Louis Prunieresa, który analizując zagadnienie kontuicji najpierw przedstawił szeroki kontekst metafizyczny tego zagadnienia, uwzględniający między innymi teorie przyczynowości, partycypacji i egzemplaryzmu ${ }^{56}$. Jednak ostateczne wyjaśnienie natury i istoty kontuicji Prunieres ulokował w obrębie samej bonawenturiańskiej epistemologii wskazując, że „dla uzyskania pewności poznania, niezbędnej do dotarcia do prawdy niezmiennej, a także zdobycia pełnej wiedzy wymagana jest kontuicja gwarantująca nam owe najważniejsze elementy strukturalne poznania ${ }^{57}$.

Kolejne stanowisko interpretacyjne to myśl ojca Léona Veuthey'a. Jego wykład tego problemu charakteryzuje się specyficzną strukturą, bowiem najpierw został zarysowany sam kontekst epistemologiczny kontuicji: „W aktualnym stanie ludzkości człowiek może naturalnie poznać Boga, ale w sposób niejasny, poprzez zwierciadło stworzeń. Nie osiąga się Boga bezpośrednio i w Nim samym, ani też przez abstrakcję z rzeczy

53 Por. „Cette appréhension indirecte par la pensée d'un object qui nous échappe, mais dont la présence est en quelque sorte impliquée dans celle des effects qui en découlent" (E. Gilson, La philosophie de saint Bonaventure, Paris 1924, s. 385).

54 Por. Une intuition serait précisément la vue directe de Dieu [...]; une contuition au sens propre n'est que l'appréhension la présence d'une cause dont l'intuition nous fait défaut" (E. Gilson, La philosophie de saint Bonaventure, dz. cyt., s. 385).

55 To zagadnienie rozwijał również E. Gilson w artykule: Pourquoi saint Thomas a critiqué saint Augustin, „Archives d'histoire doctrinale et littéraire du moyen-âge” 1 (1926-1927), por. zwłaszcza s. 119-121.

56 Por. L. Prunieres, Contuitio, w: Lexique Saint Bonaventure, ed. J.-G. Bougerol, Paris 1969, s. $42-43$.

57 Por. L. Prunieres, Contuitio, dz. cyt., s. 43-45. 
materialnych, które nie mogą dostarczyć idei Boga; dociera się do Niego w duszy, która wychodząc od rzeczy zmysłowych, w sposób naturalny dochodzi do pewnego rodzaju intuicji Boga, ujętego jako racja obecna we wszystkim i przyczyna wszystkiego. To właśnie św. Bonawentura nazywa kontuicją”58. Veuthey tak wyjaśniał: „kontuicja jest ujęciem idei Bożych [...] u kresu otwarcia się intelektu na nieskończoność. Kontuicja nie jest intuicją w ścisłym znaczeniu, ponieważ nie dociera do przedmiotu w nim samym, w jego jasności; ma jednak w sobie coś z intuicji przez to, że odnosi się do bytu konkretnego, a nie do abstrakcyjnej idei, jak to jest $\mathrm{u}$ arystotelików" "59. Zaproponowane tutaj wyjaśnienie uwzględnia więc całą strukturę bonawenturiańskiej teorii poznania ${ }^{60}$, jej metafizyczne podstawy ${ }^{61}$, stąd też to rozumienie kontuicji w tej interpretacji posiada niewątpliwie solidne osadzenie metafizyczne.

Zagadnienie prezentacji rozumienia kontuicji, jednocześnie uwzględniającej jej różnorodne konteksty (psychologiczny, epistemologiczny i metafizyczny), tak ważne dla komplementarnego wyjaśnienia interpretacyjnego, tej bardzo specyficznej formy intuicji, próbował nam podać Eward Iwo Zieliński ${ }^{62}$. Jego wyjaśnienia prezentują się następująco: „nauka o kontuicji, czyli przekonanie, że właściwie istnienie Boga jest w pewnym sensie oczywiste. Jeżeli bowiem ktoś dobrze, intuicyjnie przypatrzy się postrzeganym rzeczom, to dostrzegając ich bytową niesamodzielność, równocześnie, bez długich rozumowań, musi dostrzec fakt istnienia ich źródła, choć go intuicyjnie nie dostrzega. To tak, jak ktoś, kto wpatruje się w płynące wody rzeki, od razu wie, że gdzieś tam, może oddalone o tysiące kilometrów, znajduje się źródło, bo bez niego nie byłoby rzeki”. Według tej interpretacji ostatecznym zadaniem kontuicji jest: odkrywać przed człowiekiem metafizyczne dno rzeczywistości - a przez

${ }^{58}$ L. Veuthey, Filozofia chrześcijańska..., dz. cyt., s. 59-60.

59 L. Veuthey, Filozofia chrześcijańska..., dz. cyt., s.60.

60 O tej interpretacji zob: J. Łopat, Współczesne interpretacje..., dz. cyt., s. 61-62, 100-101; oraz J. Łopat, Filozofia św. Bonawentury, „Człowiek w Kulturze” (1998) nr 10, s. 256-259.

${ }_{61}$ Por. L. Veuthey, Filozofia chrześcijańska..., dz. cyt., s. 37-54.

62 Por. J. Łopat, Wspótczesne interpretacje..., dz. cyt., s. 98-99. Eward Iwo Zieliński nie był badaczem myśli Bonawentury, ale jego artykuł zawiera bardzo cenne spostrzeżenia w omawianej dziedzinie i właśnie dlatego został tutaj zaprezentowany. 
to - pomóc człowiekowi przyjąć odpowiedni punkt patrzenia, taki, który pozwala dostrzec Boga różnego od rzeczy, ale w rzeczach obecnego ${ }^{63}$.

Przedstawione powyżej niektóre współczesne ujęcia bonawenturiańskiej kontuicji swoim wewnętrznym pluralizmem niewątpliwie wskazują na możliwość różnorodnego odczytania oraz interpretowania tego zagadnienia. Jednak nawet taka sygnalna ich prezentacja, pozwala zauważyć, że interpretacje redukcyjne (np. Jean de Dieu de Champsecret czy też Duméry) sprowadzające całe zagadnienie kontuicji tylko do pojedynczego problemu z psychologii poznawczej, nie dają adekwatnego wytłumaczenia tego problemu, jak również deformują samą istotę poznania Boga poprzez kontuicję. Wynika to z odrzucenia przez te interpretacje metafizycznych podstaw teorii kontuicji. Podobnie próba sprowadzenia zagadnienia kontuicji tylko do specyficznego wytworu umysłu ludzkiego, zaproponowana przez interpretacje antropologiczne (Sciamanniniego czy też Bissena), jest uwikłana w pewne ukryte założenia intepretacyjne, które wymagają zaprezentowania ich metafizycznych korzeni (czyli znowu mamy problem niewystarczającego wyjaśnienia $\left.{ }^{64}\right)$. Zaprezentowane następnie epistemologiczno-metafizyczne interpretacje (Gilsona, Prunieresa, Veutheya, Zielińskiego) podawały dość zróżnicowane wyjaśnienia natury i istoty kontuicji, co niewątpliwie wynikało z uprzednio przyjętych, różnych punktów wyjścia i samych porządków dochodzenia do wyjaśnienia kontuicji ${ }^{65}$. Jednak tym ostatnim interpretacjom (epistemologiczno-metafizycznym) nie można ani postawić zarzutu redukcyjności, ani też uznać, że nie mają wystarczająco solidnego osadzenia na samych tekstach Doktora Serafickiego. Dlatego też dla właściwego i wyczerpującego wyjaśnienia jego rozumienia kontuicji konieczne jest uwzględnienie ostatecznych podstaw całej jego teorii poznania oraz samych fundamentów jego różnych koncepcji metafizycznych. Doktor Seraficki

63 E. I. Zieliński, Wykład, w: O filozoficznym poznaniu Boga dziś, red. B. Bejze, Warszawa 1992, s. 135.

${ }^{64}$ Bowiem w już podanych analizach wyraźnie daje się zauważyć, że zagadnienie kontuicji jest integralnie powiązane z różnymi aspektami metafizycznego odczytania rzeczywistości stworzonej.

65 Więcej na temat zob.Źródła różnorodności współczesnych interpretacji bonawenturiańskiej filozofii i teologii naturalnej, por. J. Łopat, Współczesne interpretacje..., s. 19-47. 
rozważając zagadnienie poznania, uznawał konieczność rozróżnienia dwóch typów poznania: jednego, które poznaje i bada rzeczywistość stworzoną tylko w aspekcie określenia jej przyczyn (stworzonych); oraz drugiego typu poznania, najbardziej ogólnego i metafizycznego, które pozwoli sensownie stawiać pytania o Pierwsza i Ostateczna Przyczynę dla całej stworzonej rzeczywistości ${ }^{66}$. Ten drugi typ poznania stanowi właściwa drogę do prawidłowego analizowania takich kwestii, jak ówcześnie gorąco dyskutowany na Uniwersytecie Paryskim filozoficzny ${ }^{67}$ problem tzw. wieczności świata ${ }^{68}$.

Warto podkreślić, iż wspomniani badacze Bonawentury, omawiając problematykę kontuicji tylko zajmowali się jej prezentacją, a nie próbowali ocenić jej wartości obiektywnej jako drogi epistemicznej do poznania Boga, stąd zwracamy się do współczesnych epistemologów z tą kwestią.

\section{Ocena kontuicji w świetle współczesnej filozofii poznania w nauczaniu wybranych autorów}

Według współczesnych badaczy, jak np. Wojciecha Chudego, to bonawenturiańska kontuicja może być zaliczana do czegoś co było nazywane przez scholastyków reflexio in actu exercito (refleksja towarzyszaca) lub conscientia concomitans (świadomość towarzyszaca) ${ }^{69}$. Dodatkowo, jak podkreślał Roman Ingarden, należy zwrócić uwagę na to, iż jest ona bardzo

${ }_{66}$ Doktor Seraficki zawsze w swoich analizach epistemologicznych podawał ich metafizyczne podłoże, stąd tak ścisłe są związki jego epistemologii z metafizyką.

67 Na ten temat zob. W. Michaś, Pierwsze antyawerroistyczne krytyki franciszkańskie, „Studia Mediewistyczne” 19 (1978) z. 2, por. zwłaszcza s. 6-7, 12-13, 17-37.

68 Por. „Ponadto, jeśli istnieje byt cząstkowy,, musi istnieć byt doskonały. I tą drogą Filozof zmierza do wykazania, że świat jest wieczny, ponieważ każdy ruch i każdą zmianę poprzedza przestrzenny ruch okrężny, gdyż jest to ruch doskonały. Lecz ja odpowiadam mu na to: należy stwierdzić, że jest prawdą, iż to, co doskonałe jest przed tym, co cząstkowe, jeśli mówimy o czymś bezgranicznie doskonałym, lecz nie o doskonałym w swoim rodzaju, a taką doskonałością jest ruch przestrzenny” (HEXA, coll. 5, 29; s. 215).

${ }_{69}$ W. Chudy, Refleksja a poznanie bytu. Refleksja ,in actu exercito" i jej funkcja w poznaniu metafizykalnym, Lublin 1984. 
swoistym, nieaktowym stanem poznawczej intuicji, którą najlepiej charakteryzuje termin intuicja przeżywania (das Durchleben) ${ }^{70}$. Natomiast Monika Walczak wyjaśnia iż: chodzi tutaj o swoisty nieaktowy moment wszystkich aktów lub stanów świadomych (dzięki któremu są one właśnie „świadome”), ujawniających podmiotowi w prosty sposób te akty lub stany w trakcie ich zachodzenia i przez sam fakt ich zachodzenia ${ }^{71}$. Tak rozumiana intuicja jest jednak różnorodnie określana: dla Franza Brentana jest to świadomość wtórna, natomiast dla Edmunda Husserla jest to praświadomość, w filozofii anglosaskiej spotkamy się z określeniem świadomości preintrospekcyjnej ${ }^{72}$, podczas gdy Stanisław Judycki preferuje raczej określenie świadomości prostej ${ }^{73}$. Jednak ocena jej znaczenia sprowadza się do zakwalifikowania jej do bycia źródłem pierwotnej wiedzy podmiotu o własnych przeżyciach, uzyskiwanej bez skierowywania na nie osobnego aktu poznawczego ${ }^{74}$. To jest najbardziej skrajna opinia negatywna współczesnych.

Kolejna grupa myślicieli, zajmując się zagadnieniem szeroko rozumianej intuicji w filozofii religii i filozofii Boga, upatruje jej roli we wskazaniu swoistej psychologiczno-przygotowawczej funkcji intuicji do osobowej asercji Absolutu. Tak zinterpretowaną funkcję intuicyjnego poznania Boga uznawali: John Henry Newmann, Søren Kierkegaard i Gabriel Mar$\mathrm{cel}^{75}$. W tej interpretacji trudno się dopatrzeć metafizycznych korzeni kontuicji i jej znaczenia dla poznania Boga, a raczej tylko jakiejś niedookreślonej funkcji mentalnego przygotowania do asercji Boga, ale to bardziej dotyczy wiary.

\footnotetext{
70 R. Ingarden, U podstaw teorii poznania, Warszawa 1971, s. 368-369.

71 M. Walczak, Intuicja jako typ poznania, wiedzy i dyspozycji, „Zagadnienia naukoznawstwa" 47 (2011) z. 2, s. 127-144.

72 R. Ziemińska, 2008, Samoświadomość i samowiedza z punktu widzenia epistemologii, „Analiza i Egzystencja" 7 (2008), s. 38.

73 S. Judycki, Świadomość i pamięć. Uzasadnienie dualizmu antropologicznego, Lublin 2004, s. 77.

74 R. Ingarden, U podstaw teorii poznania, Warszawa 1971, s. 376; D. Gierulanka, A. Polatowski, Kierunki badań filozoficznych Romana Ingardena, w: Szkice filozoficzne. Romanowi Ingardenowi $w$ darze, Warszawa 1964, s. 475. kol. 409.

75 S. Kowalczyk, Intuicjonizm, w: Encyklopedia atolicka, t. 7, red. S. Wielgus, Lublin 1997,
} 
Rolę intuicji, nawiązując do myśli Augustyna, podkreślają także zwolennicy antropologicznej argumentacji za istnieniem Boga. Według tych myślicieli, to Bóg jest intuicyjnie rozpoznawalny jako „Ty” transcendentalno-absolutne, będące dopełnieniem i fundamentem ludzkich wartości, jak np. wiary, nadziei, miłości, sprawiedliwości, dobroci. Ludzki intelekt odkrywa istnienie Praprzyczyny świata, a intuicja wyczuwa obecność niewyrażalnej tajemnicy ${ }^{76}$. Do tej grupy współczesnych myślicieli należy zaliczyć takie postaci, jak: Gabriel Marcel, Martin Buber, Fulbert Cayré ${ }^{77}$. Bonawenturiańska kontuicja nie jest jednak żadną formą przeczucia, dlatego trudno tutaj także znaleźć jakieś nawiązanie do kwestii bonawenturiańskiej kontuicji tychże interpretacji ${ }^{78}$.

Natomiast według Erica Lionela Mascall'a i Matthewa Pontifex'a dopiero człowiek, poznając bytową pochodność własną i świata, chociaż w jakiś nieokreślony sposób, to jednak intuicyjnie, rozpoznaje w nich obecność Boga jako Sprawczej Przyczyny ${ }^{79}$. Tutaj zatem dostrzega się coś, co można nazwać koncepcjami nawiązującymi do tzw. kontuicji Bonawentury, jakkolwiek żaden z myślicieli tych teorii nie uznaje samowystarczalności tejże drogi poznawczej, aby zagwarantować nam wartościowy sposób poznawania Boga.

W myśli zatem współczesnej, nawet bardzo pośrednio i bardzo daleko nawiązującej do bonawenturiańskiej kontuicji, to ciągle "krążymy” wokół jakiejś niesprecyzowanej kwestii refleksji towarzyszacej, czasem bardziej pierwotnej lub wtórnej wobec samej świadomości ludzkiej. Powstaje zatem jak najbardziej uzasadnione pytanie o przyczynę tego stanu rzeczy. Odpowiedź wydaje się być już osadzona w samych fundamentach tychże współczesnych epistemologii zasadniczo zamkniętych na transcendentny wymiar ludzkiego poznania ${ }^{80}$. Stąd dzisiejsze teorie

${ }^{6}$ Warto tutaj zauważyć wyraźne przeciwstawienie stanowiska intelektu i intuicji, a co jest dokładnie odwrotnie w myśli Bonawentury.

77 S. Kowalczyk, Intuicjonizm, dz. cyt., kol. 409.

78 Należy zawsze pamiętać iż dla Doktora Serafickiego kontuicja posiada wymiar metafizyczny, epistemologiczny i stanowi samoistną drogę poznawczą do Boga.

79 S. Kowalczyk, Intuicjonizm, dz. cyt., kol. 409.

80 Por. np. Epistemologia wspótcześnie, red. M. Hetmański, Kraków 3007; Panorama wspótczesnej filozofii, red. J. Hołówka, B. Dzikowski, Warszawa 2016, a zwłaszcza dział pt. Epistemologia, dz. cyt., s. 29-74. 
epistemologiczne są tylko fragmentaryczne, naturalistyczne, sceptyczne. Natomiast dla Bonawentury poznanie to cały proces, który zaczyna się od poznania rzeczy materialnych, zmysłowych, doczesnych, by następnie przejść przez etap nauk empirycznych, potem drogami samej filozofii, a dalej kolejno przechodzi przez etap poznania teologicznego. Kończy się poznaniem mistycznym, które to dopiero „wieńczy” cały ludzki wysiłek poznawczy. Z tego powodu dla Doktora Serafickiego musi istnieć specjalna intuicja bytowa (kontuicja), odkrywana już na poziomie najbardziej pierwotnym (pierwszego spotkania z bytem), a która systematycznie i wiernie poprowadzi umysł poznającego na sam „poznawczy szczyt”, czyli do samego Boga. Warto tutaj podkreślić, iż w zamyśle św. Bonawentury kontuicja jest to wyraźnie kwestia metafizyczna, która właściwie i prawidłowo uzasadnia nasze filozoficzne i teologicznie poprawne widzenie świata ${ }^{81}$.

81 Na przykład, dyskutowano w średniowieczu możliwość odwiecznego istnienia świata, który nota bene był lansowany przez niektórych filozofów na Uniwersytecie Paryskim, a z którą to koncepcją wytrwale walczył św. Bonawentura. Zob. np. W. Michaś, Pierwsze antyawerroistyczne..., dz. cyt., s. 6-7, 12-13, 17-37. 


\section{Summary}

Od mistycznej intuicji św. Franciszka do kontuicji św. Bonawentury

Celem niniejszego artykułu jest ukazanie, w jaki sposób św. Bonawentura z Bagnoregio próbował wyjaśnić intuicję mistyczną św. Franciszka z Asyżu. Bonawentura, jako profesor Uniwersytetu Paryskiego, zastosował do wyjaśnienia mistycznej intuicji św. Franciszka następujące teorie: teorię egzemplaryzmu, teorię zmysłów duchowych oraz swoją własną teorię tzw. kontuicji. Po zaprezentowaniu bonawenturiańskiej koncepcji kontuicji podane zostały wybrane współczesne interpretacje tejże teorii kontuicji, by następnie podać: ocenę kontuicji w świetle współczesnej filozofii poznania w nauczaniu wybranych autorów. Bonawenturiańska kontuicja jest dzisiaj niedocenianym zagadnieniem poznawczym $\mathrm{w}$ zakresie teorii poznania Boga.

Słowa kluczowe: mistyka, kontuicja, poznanie Boga, współczesna epistemologia, wartościowe poznanie

\section{From Mystical Intuition of Saint Francis towards Saint Bonaventure's Contuition}

This article aims to present how Saint Bonaventure of Bagnoregio approached the mystical intuition of Saint Francis of Assisi. As a professor of the University of Paris, in order to explain the mystical intuition of Saint Francis, Bonaventure used the following theories: the exemplarism theory, the theory of spiritual senses, and his own theory of contuition. The article outlines Bonaventure's concept of contuition as well as chosen contemporary interpretations of the theory, and then proceeds to evaluate contuition in the light of contemporary philosophy of cognition in the teachings of selected authors. Bonaventure's contuition is a much underrated concept in the cognition of God theory.

Keywords: mysticism, contuition, cognition of God, contemporary epistemology, cognition of value

Trans. by Anna Roszkowska 


\section{Bibliografia}

\section{A. Teksty Bonawentury}

Bonawentura św., Konferencje o sześciu dniach stworzenia albo oświecenia Kościoła. [Collationes in Hexaëmeron] Wydanie synoptyczne tekstu oryginalnego redakcji A oraz B z przekładem polskim, tłum. A. Horowski, Kraków 2008.

Bonawentura Święty, O wiedzy Chrystusa. O tajemnicy Trójcy, tłum. M. Olszewski, Kęty 2006.

Doctoris Seraphici S. Bonaventurae, Breviloquium, in: Opera omnia. Opuscula varia theologica, tomus quantus, Quaracchi 1891, p. 199-292.

Doctoris Seraphici S. Bonaventurae, Commentaria in primum librum Sententiarum, in: Opera omnia, vol. 1, Quaracchi 1882.

Doctoris Seraphici S. Bonaventurae, Commentaria in secundum librum Sententiarum, in: Opera omnia, vol. 2, Quaracchi 1882.

Doctoris Seraphici S. Bonaventurae, Commentaria in tertium librum Sententiarum, in: Opera omnia, vol. 3, Quaracchi 1885.

\section{B. Opracowania}

Bissen J. M., L'exemplarisme divin selon saint Bonaventure, Paris 1929.

Chudy W., Refleksja a poznanie bytu. Refleksja ,in actu exercito" i jej funkcja w poznaniu metafizykalnym, Lublin 1984.

De Dieu de Champsecret J., Itinéraire de l'Âme en elle-męme, Blois 1956.

Duméry H., Itinéraire de l'esprit vers Dieu, Paris 1960.

Epistemologia wspótcześnie, red. M. Hetmański, Kraków 2007.

Gilson E., La philosophie de saint Bonaventure, Paris 1924.

Gierulanka D., Polatowski A., Kierunki badań filozoficznych Romana Ingardena, w: Szkice filozoficzne. Romanowi Ingardenowi w darze, Warszawa 1964, s. 473-481.

Gilson E., Pourquoi saint Thomas a critiqué saint Augustin, Paris 1926, s. 5-127 (Archives d'Histoire Doctrinale et Littéraire du Moyen- Âge, 1).

Ingarden R., U podstaw teorii poznania, Warszawa 1971.

Judycki S., Świadomość i pamięć. Uzasadnienie dualizmu antropologicznego, Lublin 2004.

Kowalczyk S., Intuicjonizm, w: Encyklopedia katolicka, t. 7, red. S. Wielgus, Lublin 1997, kol. 408-410.

LaNave G. F., Bonawentura, w: Duchowe zmysty. Percepcja Boga w zachodnim chrześcijaństwie, red. P. L. Gavrilyuk, S. Coakley, tłum. A. Gomola, Kraków 2014, s. 205-222.

Łopat J., Filozofia św. Bonawentury, „Człowiek w Kulturze” (1998) nr 10, s. 256-259.

Łopat J., Rozumienie Natury Boskiej u św. Bonawentury, Niepokalanów 2017. 
Łopat J., Współczesne interpretacje poznania Boga według św. Bonawentury, Niepokalanów 1999.

Margerie de B., Osoba ludzka śladem, obrazem i podobieństwem Boga Trójcy, w: Tajemnica Trójcy Świętej, Pallottinum 2000, s. 388-395 (Kolekcja "Communio”, 13).

Michaś W., Pierwsze antyawerroistyczne krytyki franciszkańskie, „Studia Mediewistyczne" 19 (1978) z. 2, s. 6-37.

Panorama współczesnej filozofii, red. J. Hołówka, B. Dzikowski, Warszawa 2016.

Prunieres L., Contuitio, w: Lexique Saint Bonaventure, red. J.-G. Bougerol, Paris 1969, s. $42-43$.

Sciamannini P. R., La contuizione bonaventuriana, Firenze 1957.

Veuthey L., Filozofia chrześcijańska św. Bonawentury, tłum. E. I. Zieliński, Niepokalanów 1996.

Walczak M., Intuicja jako typ poznania, wiedzy i dyspozycji, „Zagadnienia naukoznawstwa" 2 (2011), s. 127-144.

Zieliński E. I., Wykład, w: O filozoficznym poznaniu Boga dziś, red. B. Bejze, Warszawa 1992, s.120-141.

Ziemińska R., Samoświadomość i samowiedza z punktu widzenia epistemologii, „Analiza i Egzystencja" 7 (2008), s. 33-51.

Zyzak W., Zmysły duchowe w duchowości chrześcijańskiej, „Analecta Cracoviensia”, 48 (2016), s. 255-276. 